I-Military drill and instruction

2-Class room and lecture instruction

3-Laboratory and plant work

4 -Visits to plants

In the course of study the men will be made familiar with the methods of manufacture, of factory control, and of inspection of explosives such as smokeless gunpowder, trinitrotolual, picric acid, ammonium nitrate, toluol, phenol, etc. The particular subjects on which emphasis is laid in the course will vary from period to period with the need for men trained for work in particular groups of plants.

While in the school each man will be rated both as to his technical performance and personal qualities exhibited. On the satisfactory completion of the course this rating will be made the basis of recommendation for a commission as second lieutenant in the Ordnance Department. The granting of commission will depend upon the number of commissions available and the varying needs of the Ordnance Department. While worthy graduates are expected to be commissioned, it is understood that commissions are not guaranteed. In any case the graduates of the school will be utilized in technical work by the Ordnance Department whether commissioned as officers or not.

The assignment of men for the first session has been completed. The second session will start about December $I$ and arrangements for assignments to it should be made about one month earlier.

The general plan is to devote the morning hours to lectures and reading, and the afternoons to laboratory practice. During the course considerable time will be spent in plants actually manufacturing explosives or explosive raw materials. In common with the enlisted men, students in the other special army school at Columbia, students in this school will have the military drill of the post, amounting to about an hour and a half daily.

First AND Second WeEKS

9-10 A.M. each day. Lectures on the general principles governing the manufacture of explosives and the tests for quality.

Io-I I A.M. two days a week. Lectures on military regulations and relations.

I-5 P.M. Laboratory practice in testing acceptable and unacceptable samples of explosive raw materials such as benzol, toluol, nitric acid, etc.

THIRD AND FoURTH WEEKS

9-IO A.M. each day. Lectures on the methods of manufacture and of testing picric acid and ammonium picrate and the raw materials from which they are made.

Io-I I A.M. two days a week. Military lectures continued.

I-5 P.M. Laboratory practice on picric acid, ammonium picrate and related materials.

Two days of the third week to be spent at a picric acid plant in New Jersey.

\section{FIFTH WEEK}

9-10 A.M. each day. Lectures on the methods of manufacture and testing of toluol, benzol, solvent naphtha and xylol.

ro-I I A.M. two days a week. Military lectures continued.

I-5 P.M. Laboratory practice with hydrocarbons.

Two, days at hydrocarbon plants in vicinity of New York City. SiXTh AND SEVENTH WeEKS

9-ro A.M. each day. Lectures on the methods of manufacture and of testing trinitrotoluol.

IO-I I A.M. two days a week. Military lectures continued.

I-5 P.M. Laboratory practice with trinitrotoluol.

Two days spent at the TNT plant at Kenville, N.J. Eighth AND Ninth WeEks

9-10 A.M. each day. Lectures on the methods of manufacture and testing of guncotton and smokeless gunpowder.

IO-I I A.M. two days a week. Military lectures continued.

I-5 P.M. Laboratory practice with guncotton and smokeless gunpowder.

Two days spent at smokeless powder plant at Parlin, N. J.

\section{TENTH WEEK}

9-IO A.M. each day. Lectures on methods of manufacture and testing of ammonium nitrate, ammonium nitrate, TNT mixtures, and shell filling.

I-5 P.M. Laboratory practice with ammonium nitrate and ammonium nitrate mixtures.

One day at shell loading plant at Perth Amboy, N. J.

Eleventh WeEk

9-10 A.M. each day. Lectures on the methods of manufacture and testing of tetryl and tetranitraniline.

I-5 P.M. Laboratory practice with tetryl and tetranitraniline.

Two days at a tetryl or tetranitraniline plant.

TWELFTH WEEK

9-Io A.M. each day. Lectures on the methods of manufacture and testing of mercury fulminate, other detonators, and fuses.

I-5 P.M. Laboratory practice in connection with detonators and fuses.

One day at plant manufacturing or using detonators, Pompton Lakes, N. J.

It is understood that the field covered by the school will vary from period to period as the needs of the Ordnance Department for men trained for work in particular types of plants may vary.

\section{CHEMISTRY FOR SOLDIERS IN TRAINING CAMPS}

Editor of the Journal of Industrial and Engineering Chemistry:

It suggests itself to me that the Publicity Committee of the AMERICAN CHEMICAL Society should extend its activities into the training camps of the United States Army.

There is no question in anybody's mind but that the war is primarily a chemical war. It has been stated that the man with the most gas will win the war.

We are desirous, as a Society, to increase the influence of chemistry and chemists in the country and the best way that we can do it to-day is to take upon ourselves as a Society to supply elemental chemical information to the soldiers of our Army. All the men have had at least public school training, so that by primitive similes, it should be possible for a speaker to make chemistry, so far as it relates to the war, at least interesting to the men in the ranks. I feel that this is a golden opportunity for us, which has not as yet, to my knowledge, been taken care of.

SAN FRANCISCO, CAI.
September 7, 1918

J. W. BECKMAN

\section{THE EMBLEM OF THE AMERICAN CHEMICAL SOCIETY}

Editor of the Journal of Industrial and Engineering Chemistry:

Mr. Charles A. Doremus' letter in the August issue of Thrs JOURNAL concerning the change of the emblem of the AMERICAN ChEMICAL SOCIETY must deserve due attention from the members of the Society. The Society's present emblem must be changed, not because it pictures an apparatus of German invention, but because the emblem does not represent chemical science in any way. Personally, I do not see how a $\mathrm{CO}_{2}$ absorption bulb can express or convey any wide thought of chemical science and its practice. The emblem of the AMERTCAN CHEmICAL SOCIETX should be of such a design that it would express the spirit and the scope of chemical science and should have a business-like and dignified appearance. I confess I do not wear the present emblem, for it is too superficial and has no scientific, technical, or business-like aspect. Something must be done to raise the standard of the Society's emblematical expression. For my part, as a member of the AMERICAN ChEmICAL Societr, I suggest that Mendeléeff's pariodic law be taken as the basis for designing a new, first-class emblem.

NATIONAL CaRbon COMPANY

GrEgory TOROSSIAN 